\title{
A PSYCHOMETRIC EVALUATION OF THE JOB DEMANDS- RESOURCES SCALE IN SOUTH AFRICA
}

\author{
S ROTHMANN \\ K MOSTERT \\ M STRYDOM \\ WorkWell: Research Unit for People, Policy and Performance, North-West University, Potchefstroom
}

\begin{abstract}
The aims of this study were to investigate the construct validity, construct equivalence and reliability of a measuring instrument of job demands and resources, and to assess the differences between the job demands and resources in different organisations in South Africa. Stratified, random samples $(\mathrm{N}=2717)$ of employees in different organisations were taken. Five reliable factors were extracted using principal component analysis with a varimax rotation, namely overload, growth opportunities, organisational support, advancement, and job insecurity. All factors, except organisational support, showed acceptable equivalence for different organisations. Statistically significant differences were found between the perceptions of job demands and resources in different organisations.
\end{abstract}

Key words

Job demands, job resources, reliability, validity, equivalence

Over the last few decades, the nature of work changed significantly. The increased utilisation of information and communication technology, the expansion of the service sector, the globalisation of the economy, the changing structure of the workforce, the increasing flexibilisation of work, the creation of the 24-hour economy, and the application of new production concepts had significant effects on the nature of work (Rothmann \& Cilliers, 2004). The nature of work has also changed from manual demands to more mental and emotional demands (Turner, Barling \& Zacharatos, 2002). Employment relationships have changed dramatically, adjusting the type of work that people do, when they work, and how much work they do (Barling, 1999).

Work might impact on the well-being of employees. Two theoretical models could be used to understand the effects of work on the well-being of employees. First, according to the holistic model of well-being (Nelson \& Simmons, 2003), demands and resources in an organisation might lead to distress (e.g. burnout) or eustress (e.g. engagement). Second, according to the dual-process model (Schaufeli \& Bakker, 2004), job demands and resources might affect physical health, psychological wellbeing and organisational commitment through certain mediating factors (i.e. burnout and work engagement). Therefore, job demands and resources could be regarded as important causes of well-being at work (Demerouti, Bakker, Nachreiner \& Schaufeli, 2001; Schaufeli \& Bakker, 2004).

The determinants of well-being may differ within various working environments, depending on the unique demands and resources that exist in the specific work context. Furthermore, it seems that every occupation (or organisation) has its own specific risk factors regarding well-being. For example, burnout of employees in call centres is primarily caused by emotional load (Zapf, Vogt, Seifert, Mertini \& Isic, 1999). Work overload and lack of autonomy seems to be important stressors for production workers (De Jonge \& Kompier, 1997). For educators, interaction with learners is the most important determinant of burnout (Van Horn, Schaufeli \& Enzmann, 1999). Little scientific information exists regarding the job demands and resources in different organisations in South Africa.

Various models have been tested with regard to the effects of job demands and resources on well-being of employees. Karasek (1979) developed the Job Demands-Control model as an approach to job stress. The assumption of this model is that effective job control or decision-making is an important resource that could moderate the negative effects of job stress (Karasek \& Theorell,
1990). Therefore, increasing job control could reduce the occurrence of job strain. The Job Characteristics model (Hackman \& Oldham, 1980) assumes that there is a linear relationship between job characteristics (including skill variety, task identity, task significance, autonomy and feedback) and employee well-being. According to the Vitamin model (Warr, 1987), mental health (conceptualised in terms of three dimensions, namely pleasure/displeasure, anxiety/comfort, and depression/enthusiasm) can be affected by environmental factors such as opportunity for control, opportunity for skill use, job demands, variety, feedback and job security, and social support, as well as availability of money, good working conditions and occupational prestige.

Although the above-mentioned models might be useful to explain the effect of job characteristics on well-being, studies have reported problems with these models (De Jonge \& Kompier, 1997; Terry \& Jimmieson, 1999). For example, most of the models use organisational approaches to investigate workrelated well-being, which are usually descriptive in nature; that is, instead of explaining work-related well-being, they describe what types of organisational variables are related to well-being (Schaufeli, 2003).

The Job Demands-Resources model assumes that two underlying psychological processes play a role in well-being of individuals: an effort-driven process in which excessive job demands and a lack of job resources lead to distress, and a motivation-driven process in which job resources lead to work engagement (Demerouti et al., 2001; Schaufeli \& Bakker, 2004). Although several international studies used this model to explain the influence of job demands and resources on well-being (e.g. Bakker, Demerouti \& Schaufeli, 2003; Bakker, Demerouti, Taris, Schaufeli \& Schreurs, 2003; Schaufeli \& Bakker, 2004), research is needed regarding the job demands and resources as experienced by employees in different organisations in South Africa.

A valid and reliable instrument is needed to measure job demands and resources and to compare them in different organisations. Although Jackson and Rothmann (2005) developed a questionnaire to measure job demands and resources, the psychometric properties of this instrument have not yet been investigated in different South African organisations. Furthermore, before the job demands and resources in different organisations can be compared, it is necessary to assess the construct equivalence (factorial invariance) of the measuring instrument in these contexts. Construct equivalence indicates the extent to which the same 
construct is measured across the cultural groups under study; in other words, the comparison of cultural groups, seeing that their scores are related to the same construct. If cultural influences (inherent in different organisations) are not accounted for, invalid conclusions regarding the constructs under study could be made - with serious implications for diverse organisational settings (Van de Vijver \& Leung, 1997).

The aims of this study were to investigate the construct validity, construct equivalence and reliability of a measuring instrument of job demands and resources, and to assess the differences between the job demands and resources in different organisations in South Africa.

\section{The job demands-resources model}

Demerouti et al. (2001) developed the Job Demands-Resources (JD-R) model. One central assumption of the JD-R model is that, although every occupation (or organisation) may have its own specific work characteristics associated with well-being, it is still possible to model these characteristics in two broad categories, namely job demands and job resources.

Job demands represent aspects of the job that could potentially cause strain in cases where they exceed the employee's adaptive capability. More specifically, job demands refer to physical, social or organisational aspects of a job that require sustained physical and/or psychological effort on the part of the employee and that are therefore associated with certain physiological and/or psychological costs (Schaufeli \& Bakker, 2004). Job demands are not negative, but may lead to job stress when employees are confronted by demands which require effort when they have not recovered from stress caused by previous demands (Meijman \& Mulder, 1998). Karasek (1979) identifies various influential demands and recognises a restricted definition of job demands that are mainly quantitative in nature, such as workload and time pressure. The JD-R model supports this view by recognising that demanding characteristics of the working environment, work pressure, overload, emotional demands, and poor environmental conditions may lead to the impairment of health and ultimately to absenteeism (Schaufeli \& Bakker, 2004; Semmer, Zapf \& Dunckel, 1995; Zapf et al., 1999).

Job resources concern the extent to which the job offers assets/opportunities to individual employees. Job resources refer to those physical, psychological, social or organisational aspects of the job that: (1) reduce job demands and the associated physiological and psychological costs, (2) are functional in achieving work goals, and/or (3) stimulate personal growth, learning, and development (Demerouti et al., 2001). Thus, resources are not only necessary to deal with job demands, but also are important in their own right (Elsass \& Veiga, 1997; Ganster \& Fusilier, 1989; Hobfoll, 2001; Terry \& Jimmieson, 1999).

Resources may be placed at the level of the organisation (e.g. salary, career opportunities, job security), at the level of interpersonal and social relations (e.g. supervisor and coworker support, team climate), at the level of the organisation of work (e.g. role clarity, participation in decision making), and at the level of the task (e.g. performance feedback, skill variety, task significance, task identity, autonomy). Resources at the level of the task induce so-called critical psychological states (e.g. meaningfulness), which drive people's attitudes and behaviours (Hackman \& Oldham, 1980). Job resources play an intrinsic motivational role (by developing employee growth, learning and development) or an extrinsic motivational role (by being instrumental in achieving work goals) (Schaufeli \& Bakker, 2004).

The Conservation of Resources (COR) theory (Hobfoll, 1998, 2001) is a relevant theory for understanding the effects of job resources (or the lack thereof) on employees. The COR theory's central tenet is that people strive to obtain, retain and protect what they value. Resources are those personal energies and characteristics, objects and conditions that are valued by individuals or that serve as means for the attainment of other objects, personal characteristics, conditions or energies. Examples of resources include social support, job enhancement opportunities, degree of participation in decision making, being psychologically well or having an optimistic personality, level of autonomy, and established behaviour outcome contingencies (Hobfoll, 1989; Lee \& Ashforth, 1996). The COR theory argues that personal resources affect each other and exist as a resource pool, and that an expansion of one is often associated with the other one being augmented (Hobfoll, 1999).

When the external environment lacks resources, individuals cannot reduce the potentially negative influence of high job demands (e.g. overload, role ambiguity, and role conflict) and they cannot achieve their work goals. Additionally, they cannot develop themselves further in their job and organisation. The COR theory predicts that, in such a situation, employees will experience a loss of resources or failure to gain an investment (Hobfoll, 1989; Hobfoll \& Freedy, 1993). Moreover, in order to reduce this discomfort of job stress, employees will attempt to minimise losses. With the intention of achieving equity without further negative consequences for themselves, they will most probably reduce their discretionary inputs. Based on the holistic model or work-related well-being (Nelson \& Simmons, 2003), it could be expected that perceptions of job demands and resources could result in negative psychological experiences (i.e. distress) or positive psychological experiences (i.e. eustress). Certain organisations that are characterised by high demands and low resources are stressful, whereas organisations with high demands and resources tend to be challenging (Jackson \& Rothmann, 2005).

\section{Job demands and resources in different organisations}

Occupational stress research in South Africa shows that different organisations do experience different types of job demands and job resources (Rothmann, 2005). The environments in which employees in different organisations find themselves differ. Therefore, it could be expected that the job demands and resources as perceived by staff members of universities of technology, academics in higher education institutions, employees in the insurance industry, engineers and correctional officers will differ.

Educators in South African schools faced a dramatic increase in workload in terms of learner numbers over the past two years (Naidu, 2005). According to Jackson and Rothmann (2005), overload, a lack of growth opportunities and low control are major predictors of exhaustion of educators. Doyle and Hind (1998) found that educators work long hours, although as many as $40 \%$ of educators found their work enjoyable, motivating and rewarding. These factors affect education on primary, secondary and tertiary levels in South Africa.

Educators at higher education institutions in South Africa are faced by large student numbers, students from a poor educational background, a lack of resources, and organisational transformation which resulted from mergers of many of these institutions. In 2005, R10,7 billion was spend on higher education in South Africa, which represents 13,4\% of the total education budget (Rothmann, 2005). Resources allocated to higher education institutions have decreased due to the competing demands of the state (Koorts, 2000). A premium is also placed on the professional identity of the university teacher as a researcher, capable of attracting external funds within an increasingly competitive research culture (Nixon, Marks, Rowland \& Walker, 2001). Fisher (1994) suggested that such a plethora of roles might easily 
result in role overload, a particular salient stressor for the modern academic.

The insurance industry seems to be experiencing rapid changes. It has expanded dramatically over the last few years because of fast economic growth, urbanisation and increased education, which has led to high competitiveness and rivalries between companies and employees (Chan, 2002). Currently, this field of work is experiencing intense business pressures. Executives are under pressure to expand into new markets, to boost margins and to grow market share. It requires more emphasis on crossselling to customers and on being able to provide superior service at reduced costs while directing customers to more profitable products. It also requires expanding and supporting the agent/sales force with minimal impact on operations. Lai, Chan, Ko and Boey (2000) found that insurance staff experience high job insecurity, a lack of variety and control, high workload and poor interpersonal relations (Lindstrom, Leino, Seitsamo \& Tordtila, 1997). In a South African study, Coetzer (2004) found that employees in the insurance industry experience high levels of job insecurity.

Compared to the past, engineers in South Africa currently have to invest more in their jobs in terms of time, effort, skill, and flexibility, whereas they receive less in terms of career opportunities, lifetime employment and job security. Today's engineers have less time, more work, and a growing need for information (Lingard, 2003). Furthermore, engineers need to be equipped with ways to build and capitalise on their strengths to maintain excellent performance.

Correctional officers perform jobs which are basically clientcentred in their orientation. Such jobs involve working intensely and intimately with other people, trying to help them or to perform services to them (Finn, 1998). As the prison population continues to increase, the conditions within correctional facilities will remain stressful for inmates (Hassine, 1996; Toch, 1992) and staff (Anson \& Bloom, 1988; Finn, 1998) alike. Although inmates have numerous programs available to help them cope with the stress of their living environment (e.g. stress management programmes), correctional officers have limited resources designed to help them cope with the stress of the prison environment. To further compound the problem, correctional environments are typically considered "tough" and "dangerous" places of employment (Maghan \& McLeishBlackwell, 1991). Therefore, correctional officers often experience high demands (Flanagan, Johnson \& Wesley, 1996), including role conflict because of custodial demands (Anson, Johnson \& Anson, 1997). In addition, Rothmann (2005) showed that correctional services experience a lack of organisational support and a lack of control.

\section{RESEARCH DESIGN}

\section{Participants}

A stratified, random sample $(\mathrm{N}=2717)$ of employees in different working groups and environments was taken. The participants consisted of employees in the insurance industry, the engineering industry, and in correctional services, as well as staff members at a university of technology, and academics within higher education institutions (see Table 1).

Table 1 shows that $58,2 \%$ of the participants were male, $47,6 \%$ Afrikaans speaking and $25,4 \%$ English speaking. Most of the respondents were between the ages of 30 and $39(40,3 \%)$.

\section{Measuring instrument}

The Job Demands-Resources Scale (JDRS) was developed by Jackson and Rothmann (2005) to measure job demands and job resources. The scale was developed based on a literature review as well as interviews with participating groups in this study. Items were developed and checked for face validity. The JDRS consists of 40 items about pace and amount of work, mental load, emotional load, variety in work, opportunities to learn, independence in work, relationships with colleagues, relationship with immediate supervisor, ambiguities about work, information, communications, participation, contact possibilities, uncertainty about the future, remuneration, and career possibilities. The items were rated on a four-point scale ranging from 1 (never) to 4 (always). Jackson and Rothmann (2005) found that the dimensions of the JDRS consisted of seven reliable factors, namely organisational support $(\alpha=0,88)$, growth opportunities $(\alpha=0,80)$, overload $(\alpha=0,75)$, job insecurity $(\alpha=0,90)$, relationship with colleagues $(\alpha=0,76)$, control $(\alpha=0,71)$, and rewards $(\alpha=0,78)$.

\section{TABLE 1}

Charateristics of The Participants

\begin{tabular}{|c|c|c|c|}
\hline Item & Category & Frequency & Percentage \\
\hline \multirow[t]{5}{*}{ Organisation } & Insurance Industry & 613 & 22,6 \\
\hline & Engineering Industry & 369 & 13,6 \\
\hline & Correctional Officers & 892 & 32,8 \\
\hline & University of Technology & 372 & 13,7 \\
\hline & $\begin{array}{l}\text { Academics (Higher } \\
\text { Education Institutions) }\end{array}$ & 471 & 17,3 \\
\hline \multirow[t]{2}{*}{ Gender } & Male & 1581 & 58,2 \\
\hline & Female & 1100 & 40,5 \\
\hline \multirow[t]{12}{*}{ Language } & Afrikaans & 1293 & 47,6 \\
\hline & English & 689 & 25,4 \\
\hline & Pedi & 114 & 4,2 \\
\hline & Sotho & 128 & 4,7 \\
\hline & Tswana & 103 & 3,8 \\
\hline & Swati & 7 & 0,3 \\
\hline & Venda & 16 & 0,6 \\
\hline & Zulu & 111 & 4,1 \\
\hline & Ndebele & 21 & 0,8 \\
\hline & Xhosa & 205 & 7,5 \\
\hline & Tsonga & 13 & 0,5 \\
\hline & Other & 3 & 0,1 \\
\hline \multirow[t]{7}{*}{ Education } & Highest Grade/Standard & 68 & 2,5 \\
\hline & 3-year Degree & 876 & 32,2 \\
\hline & 4-year Degree/Honours & 567 & 20,9 \\
\hline & 5-7-year Degree & 329 & 12,1 \\
\hline & Master's Degree & 379 & 13,9 \\
\hline & Doctoral Degree & 410 & 15,1 \\
\hline & Other & 30 & 1,1 \\
\hline \multirow[t]{4}{*}{ Age } & $15-29$ & 437 & 16 \\
\hline & $30-39$ & 1096 & 40,3 \\
\hline & $40-49$ & 628 & 25 \\
\hline & $50-59$ & 337 & 12,2 \\
\hline
\end{tabular}

\section{Statistical analysis}

The statistical analysis was carried out with the SPSS program (SPSS Inc., 2003). Descriptive statistics were used to explore the data. Cronbach alpha coefficients were calculated to assess the reliability of the constructs measured in this study. Exploratory factor analyses were carried out to investigate the construct validity of the measuring instruments. First, a simple principal component analysis was conducted on the constructs that form part of the measurement model, namely job demands and resources. The eigenvalues and scree plot were studied to determine the number of factors. Second, a principal component analysis with a direct oblimin rotation was conducted if factors were related, and a principal component analysis with a varimax rotation was used if the obtained factors were not related (Tabachnick \& Fidell, 2001). 
Construct equivalence of the JDRS was also performed. According to Van de Vijver and Leung (1997), construct equivalence can be investigated with several techniques, such as factor analysis, cluster analysis, and multidimensional scaling or other dimensionality-reducing techniques. Factor analysis is the most frequently employed technique for studying construct equivalence, especially when little information exists regarding the factor structure of a measuring instrument (as is the case with the JDRS). Factors obtained in each group were compared with the pooled solution (after target rotation). The agreement was evaluated by a factor congruence coefficient, Tucker's phi (Van de Vijver \& Leung, 1997). Values above 0,90 were taken to point to essential agreement between cultural groups, while values above 0,95 pointed to very good agreement. A high agreement implied that the factor loadings of the lower and higher levels were equal up to a multiplying constant.

Pearson product-moment correlation coefficients were used to specify the relationship between the variables. In terms of statistical significance, it was decided to set the value at a 95\% confidence interval level ( $\mathrm{p}<0,05)$. Effect sizes (Steyn, 1999) were used to decide on the practical significance of the findings. A cut-off point of 0,30 (medium effect, Cohen, 1988) was set for the practical significance of correlation coefficients.

Multivariate analysis of variance (MANOVA) was used to assess the significance of differences between job demands and job resources with the different organisational groups. MANOVA tests whether mean differences among groups in a combination of dependent variables are likely to have occurred by chance (Tabachnick \& Fidell, 2001). A new dependent variable that maximises group differences will be created from a set of dependant variables. A one-way analysis of variance was then performed. Wilks' Lambda was used to test the significance of the effects. Wilks' Lambda is a likelihood ratio statistic of the data under the assumption of the equal population mean vectors for all the groups against the likelihood under the assumption that the population mean vectors are identical to those of the sample mean vectors for the different groups.

\section{RESULTS}

Factor structure and construct equivalence of the JDRS

A simple principal component analysis was conducted on the items of the Job Demands-Resources Scale (JDRS) to assess the number of factors. An analysis of the eigenvalues showed that nine factors could be extracted. However, the scree plot showed that five factors could be extracted, which explained $49,81 \%$ of the total variance. The eigenvalues of these factors were as follows: Factor $1=10,61$; Factor $2=3,34$; Factor $3=2,90$; Factor $4=2,31$; and Factor $5=1,76$.

A principal component analysis was conducted on the pooled solution (i.e. all the participants were included in the same analysis). The results of the principal component analysis with a varimax rotation are illustrated in Table 2.

Table 2 shows that 45 of the 48 items loaded on the five factors. Factor 1 was labelled Growth Opportunities. This factor refers to having enough variety, opportunities to learn and independence in the job. Factor 2 was labelled Organisational Support. This factor refers to the relationship with supervisors and colleagues, flow of information, communication, role clarity and participation in decision-making. Factor 3 was labelled Advancement. This factor includes items relating to remuneration, career possibilities and training opportunities. Factor 4 was labelled Overload and includes items relating to

pace and amount of work, mental load and emotional load. Factor 5 was labelled Job Insecurity. This factor refers to uncertainty about the future.

In Table 3, the rotated component matrix of each organisation was compared with the pooled solution to assess whether they are equivalent. The Tucker's phi coefficients for the JDRS in different organisations are reported in Table 4.

TABLE 2

Principal Component analysis With a Varimax ROTATION ON THE POOLED SOLUTION

\begin{tabular}{|c|c|c|c|c|c|}
\hline & Factor 1 & Factor 2 & Factor 3 & Factor 4 & Factor 5 \\
\hline $\begin{array}{l}\text { Do you have too much } \\
\text { work to do? }\end{array}$ & $-0,07$ & 0,13 & $-0,09$ & 0,65 & 0,02 \\
\hline $\begin{array}{l}\text { Do you work under } \\
\text { time pressure? }\end{array}$ & $-0,07$ & 0,03 & $-0,04$ & 0,72 & $-0,09$ \\
\hline $\begin{array}{l}\text { Do you have to be attentive } \\
\text { to many things at the } \\
\text { same time? }\end{array}$ & 0,01 & 0,05 & $-0,02$ & 0,71 & $-0,06$ \\
\hline $\begin{array}{l}\text { Do you have to give } \\
\text { continuous attention to } \\
\text { your work? }\end{array}$ & 0,14 & 0,23 & $-0,15$ & 0,55 & 0,08 \\
\hline $\begin{array}{l}\text { Do you have to remember } \\
\text { many things in your work? }\end{array}$ & 0,11 & 0,18 & $-0,14$ & 0,59 & 0,08 \\
\hline $\begin{array}{l}\text { Are you confronted in your } \\
\text { work with things that affect } \\
\text { you personally? }\end{array}$ & $-0,15$ & $-0,11$ & 0,11 & 0,57 & 0,02 \\
\hline $\begin{array}{l}\text { Do you have contact with } \\
\text { difficult people in your work? }\end{array}$ & $?^{-0,01}$ & $-0,03$ & 0,06 & 0,48 & 0,01 \\
\hline $\begin{array}{l}\text { Does your work put you in } \\
\text { emotionally upsetting } \\
\text { situations? }\end{array}$ & $-0,20$ & $-0,14$ & 0,05 & 0,59 & 0,04 \\
\hline $\begin{array}{l}\text { Do you have enough variety } \\
\text { in your work? }\end{array}$ & 0,17 & 0,56 & 0,17 & 0,23 & 0,00 \\
\hline $\begin{array}{l}\text { Does your job offer you } \\
\text { opportunities for personal } \\
\text { growth and development? }\end{array}$ & 0,21 & 0,64 & 0,32 & 0,09 & $-0,01$ \\
\hline $\begin{array}{l}\text { Does your work give you } \\
\text { the feeling that you can } \\
\text { achieve something? }\end{array}$ & 0,23 & 0,68 & 0,28 & 0,06 & $-0,03$ \\
\hline $\begin{array}{l}\text { Does your job offer you } \\
\text { the possibility of independent } \\
\text { thought and action? }\end{array}$ & 0,29 & 0,73 & 0,15 & 0,10 & $-0,04$ \\
\hline $\begin{array}{l}\text { Do you have freedom in } \\
\text { carrying out your work } \\
\text { activities? }\end{array}$ & 0,33 & 0,62 & 0,06 & $-0,06$ & $-0,06$ \\
\hline $\begin{array}{l}\text { Do you have influence in } \\
\text { the planning of your work } \\
\text { activities? }\end{array}$ & 0,24 & 0,65 & 0,03 & 0,04 & $-0,04$ \\
\hline $\begin{array}{l}\text { Can you participate in the } \\
\text { decision about when a piece } \\
\text { of work must be completed? }\end{array}$ & 0,26 & 0,61 & 0,06 & $-0,01$ & 0,03 \\
\hline $\begin{array}{l}\text { Can you count on your } \\
\text { colleagues when you come } \\
\text { across difficulties in } \\
\text { your work? }\end{array}$ & 0,48 & 0,29 & $-0,04$ & $-0,06$ & 0,13 \\
\hline $\begin{array}{l}\text { If necessary, can you ask } \\
\text { your colleagues for help? }\end{array}$ & 0,46 & 0,25 & $-0,06$ & $-0,11$ & 0,12 \\
\hline $\begin{array}{l}\text { Do you get on well with } \\
\text { your colleagues? }\end{array}$ & 0,44 & 0,20 & $-0,09$ & $-0,08$ & 0,14 \\
\hline $\begin{array}{l}\text { Can you count on your } \\
\text { supervisor when you come } \\
\text { across difficulties in } \\
\text { your work? }\end{array}$ & 0,73 & 0,13 & 0,07 & $-0,04$ & $-0,00$ \\
\hline $\begin{array}{l}\text { Do you get on well with } \\
\text { your supervisor? }\end{array}$ & 0,75 & 0,09 & 0,05 & $-0,05$ & $-0,00$ \\
\hline $\begin{array}{l}\text { In your work, do you feel } \\
\text { appreciated by your } \\
\text { supervisor? }\end{array}$ & 0,78 & 0,11 & 0,19 & 0,00 & $-0,04$ \\
\hline $\begin{array}{l}\text { Do you know exactly what } \\
\text { other people expect of you } \\
\text { in your work? }\end{array}$ & 0,55 & 0,24 & $-0,00$ & $-0,02$ & $-0,02$ \\
\hline $\begin{array}{l}\text { Do you know exactly for } \\
\text { what you are responsible? }\end{array}$ & 0,48 & 0,35 & $-0,06$ & $-0,06$ & 0,03 \\
\hline
\end{tabular}




\begin{tabular}{|c|c|c|c|c|c|}
\hline $\begin{array}{l}\text { Do you know exactly what } \\
\text { your direct supervisor thinks } \\
\text { of your performance? }\end{array}$ & 0,73 & 0,07 & 0,19 & 0,05 & $-0,09$ \\
\hline $\begin{array}{l}\text { Do you receive sufficient } \\
\text { information on the purpose } \\
\text { of your work? }\end{array}$ & 0,68 & 0,23 & 0,17 & 0,00 & $-0,08$ \\
\hline $\begin{array}{l}\text { Do you receive sufficient } \\
\text { information on the results } \\
\text { of your work? }\end{array}$ & 0,68 & 0,20 & 0,21 & 0,02 & $-0,06$ \\
\hline $\begin{array}{l}\text { Does your direct supervisor } \\
\text { inform you about important } \\
\text { issues within your } \\
\text { department/organisation? }\end{array}$ & 0,74 & 0,07 & 0,25 & 0,04 & $-0,05$ \\
\hline $\begin{array}{l}\text { Are you kept adequately up- } \\
\text { to-date about important issues } \\
\text { within your organisation? }\end{array}$ & 0,55 & 0,32 & 0,21 & $-0,01$ & $-0,04$ \\
\hline $\begin{array}{l}\text { Is the decision-making } \\
\text { process of your organisation } \\
\text { clear to you? }\end{array}$ & 0,46 & 0,35 & 0,26 & $-0,03$ & $-0,03$ \\
\hline $\begin{array}{l}\text { Is it clear to you whom you } \\
\text { should address within the } \\
\text { organisation for specific } \\
\text { problems? }\end{array}$ & 0,51 & 0,35 & 0,06 & $-0,09$ & 0,04 \\
\hline $\begin{array}{l}\text { Can you discuss work } \\
\text { problems with your direct } \\
\text { supervisor? }\end{array}$ & 0,75 & 0,18 & 0,07 & $-0,04$ & $-0,04$ \\
\hline $\begin{array}{l}\text { Can you participate in } \\
\text { decisions about the nature } \\
\text { of your work? }\end{array}$ & 0,54 & 0,48 & 0,11 & $-0,02$ & $-0,03$ \\
\hline $\begin{array}{l}\text { Do you have a direct } \\
\text { influence on your } \\
\text { organisation's decisions? }\end{array}$ & 0,30 & 0,44 & 0,25 & 0,09 & $-0,04$ \\
\hline $\begin{array}{l}\text { Do you need to be more } \\
\text { secure that you will still be } \\
\text { working in one year's time? }\end{array}$ & $-0,02$ & $-0,03$ & $-0,03$ & 0,04 & 0,88 \\
\hline $\begin{array}{l}\text { Do you need to be more } \\
\text { secure that you will keep } \\
\text { your current job in the } \\
\text { next year? }\end{array}$ & $-0,01$ & $-0,05$ & $-0,04$ & 0,04 & 0,92 \\
\hline $\begin{array}{l}\text { Do you need to be more } \\
\text { secure that next year you } \\
\text { will keep the same function } \\
\text { level as currently? }\end{array}$ & $-0,02$ & $-0,03$ & $-0,02$ & 0,04 & 0,84 \\
\hline $\begin{array}{l}\text { Do you think that your } \\
\text { organisation pays good } \\
\text { salaries? }\end{array}$ & 0,14 & 0,12 & 0,78 & $-0,00$ & 0,02 \\
\hline $\begin{array}{l}\text { Can you live comfortably } \\
\text { on your pay? }\end{array}$ & 0,09 & 0,10 & 0,79 & 0,02 & $-0,03$ \\
\hline $\begin{array}{l}\text { Do you think you are paid } \\
\text { enough for the work that } \\
\text { you do? }\end{array}$ & 0,08 & 0,03 & 0,80 & $-0,10$ & $-0,02$ \\
\hline $\begin{array}{l}\text { Does your job offer you } \\
\text { the possibility to progress } \\
\text { financially? }\end{array}$ & 0,13 & 0,24 & 0,75 & $-0,01$ & $-0,03$ \\
\hline $\begin{array}{l}\text { Does your organisation give } \\
\text { you opportunities to follow } \\
\text { training courses? }\end{array}$ & 0,24 & 0,32 & 0,38 & $-0,06$ & $-0,02$ \\
\hline $\begin{array}{l}\text { Does your job give you the } \\
\text { opportunity to be promoted? }\end{array}$ & 0,13 & 0,30 & 0,52 & $-0,02$ & $-0,04$ \\
\hline
\end{tabular}

Tables 3 and 4 show that the factor structure of the JDRS is equivalent for different organisations. The Tucker's phi coefficients compared favourably with the guideline of 0,90 . The only exception was the Tucker's phi of the second factor in the Engineer group. The coefficient was slightly lower than the cut-off point of 0,90 . Table 3 shows that there are two reasons for this slightly lower Tucker's phi value on organisational support. First, in the correctional officer sample as well as in university of technology sample, three items related to support of colleagues had relatively strong cross-loadings on another factor, namely growth opportunities. Second, one item ("Do you have a direct influence on your organisation's decisions"), which is supposed to from part of organisational support, loaded on another factor (growth opportunities) in the correctional officer sample as well as the sample of employees in the insurance industry.

Descriptive statistics, alpha coefficients and correlations The descriptive statistics, alpha coefficients and correlations of the JDRS are reported in Table 5.

Table 5 shows that highly acceptable alpha coefficients, ranging from 0,76 to 0,92 , were obtained (Nunnally \& Bernstein, 1994). Thus, the scale shows acceptable internal consistency reliability. Table 5 shows that growth opportunities are practically significantly related to organisational support (large effect), and advancement (medium effect). Organisational support is practically significantly related to advancement (medium effect).

Subsequently, a principal component analysis was carried out on the correlations of the five first-order factors. Two factors, with eigenvalues of 2,08 and 1,03 respectively, were extracted. These two factors explained $62,20 \%$ of the total variance. The first factor was labelled Job Demands, and included overload (loading $=0,98$ ). The second factor was labelled Job Resources, and included growth opportunities $(0,84)$, organisational support $(0,84)$, job insecurity $(-0,32)$, and advancement $(0,75)$.

\section{Differences between groups}

Next, multivariate analysis of variance (MANOVA) was used to determine the significance of differences between job demands and job resources in different organisational groups (see Table 6). In MANOVA, several dependent variables (in this case overload, organisational support, growth opportunities, job insecurity and advancement) are considered together in the same analysis. The means and standard deviations of the job demands and resources for different biographical groups are reported in Table 7.

Table 7 shows a statistically significant effect of the organisation on the combined dependent variable job demands/resources $(\mathrm{F}=$ 52,01; $<<0,01$; Wilks' Lambda $=0,70 ; \eta^{2}=0,09$ ). This effect was moderate (explaining $9 \%$ of the variance in job demands/resources). Organisation explained $15 \%$ of the variance in job insecurity, $8 \%$ of the variance in growth opportunities, and $8 \%$ of the variance in advancement. Furthermore, organisation explained $7 \%$ of the variance in overload explained and $5 \%$ of the variance in organisational support.

Engineers showed statistically significantly higher scores on overload than employees in the insurance industry. Correctional officers experienced less job demands (overload) than the insurance staff as well as the university of technology and academics in higher education institutions. Engineers and academics in higher education institutions experienced the highest overload. Engineers experienced the highest growth opportunities of all the organisations. Academics in higher education institutions also experienced more growth opportunities than the other groups, while correctional officers experienced the least growth opportunities.

Engineers, academics in higher education institutions and employees in the insurance industry reported higher levels of organisational support than correctional officers and employees of a university of technology. Engineers obtained higher scores on advancement than the other groups. However, academics in higher education institutions reported the least advancement opportunities. Job insecurity was the highest for correctional officers and employees of a university of technology, and the lowest for engineers. 
TABLE 3

Principal COMPonent ANALYSIS WITH VARIMAX Rotation ON THE INDIVIDUAL GROUPS

\begin{tabular}{|c|c|c|c|c|c|c|c|c|c|c|c|c|c|c|c|}
\hline & \multicolumn{5}{|c|}{ Group 1: Insurance } & \multicolumn{5}{|c|}{ Group 2: Engineers } & \multicolumn{5}{|c|}{ Group 3: Correctional Officers } \\
\hline & 1 & 2 & 3 & 4 & 5 & 1 & 2 & 3 & 4 & 5 & 1 & 2 & 3 & 4 & 5 \\
\hline Do you have too much work to do? & 0,02 & $-0,10$ & $-0,14$ & 0,65 & 0,05 & 0,12 & 0,10 & 0,63 & 0,03 & $-0,04$ & $-0,03$ & 0,20 & $-0,03$ & 0,63 & $-0,00$ \\
\hline Do you work under time pressure? & $-0,16$ & $-0,05$ & $-0,01$ & 0,71 & $-0,04$ & 0,07 & 0,12 & 0,72 & 0,03 & $-0,03$ & $-0,05$ & 0,01 & 0,02 & 0,73 & $-0,09$ \\
\hline $\begin{array}{l}\text { Do you have to be attentive to many things at } \\
\text { the same time? }\end{array}$ & 0,02 & $-0,03$ & 0,17 & 0,71 & $-0,12$ & 0,09 & 0,11 & 0,69 & 0,12 & 0,00 & $-0,01$ & 0,04 & $-0,03$ & 0,70 & $-0,08$ \\
\hline $\begin{array}{l}\text { Do you have to give continuous attention } \\
\text { to your work? }\end{array}$ & 0,11 & 0,21 & $-0,14$ & 0,66 & 0,06 & 0,24 & 0,18 & 0,57 & 0,04 & 0,05 & 0,12 & 0,33 & $-0,12$ & 0,48 & 0,09 \\
\hline Do you have to remember many things in your work? & $-0,00$ & 0,15 & $-0,03$ & 0,69 & 0,10 & 0,14 & 0,08 & 0,66 & $-0,04$ & 0,01 & 0,05 & 0,24 & $-0,07$ & 0,56 & 0,11 \\
\hline $\begin{array}{l}\text { Are you confronted in your work with things that } \\
\text { affect you personally? }\end{array}$ & $-0,01$ & $-0,23$ & 0,06 & 0,52 & 0,00 & $-0,03$ & $-0,09$ & 0,45 & 0,06 & 0,02 & $-0,09$ & $-0,20$ & 0,14 & 0,59 & $-0,03$ \\
\hline $\begin{array}{l}\text { Do you have contact with difficult people in } \\
\text { your work? }\end{array}$ & 0,07 & $-0,15$ & 0,37 & 0,28 & $-0,05$ & 0,13 & $-0,13$ & 0,56 & $-0,13$ & $-0,03$ & 0,01 & $-0,04$ & $-0,07$ & 0,50 & 0,13 \\
\hline $\begin{array}{l}\text { Does your work put you in emotionally } \\
\text { upsetting situations? }\end{array}$ & 0,02 & $-0,32$ & 0,04 & 0,50 & 0,08 & $-0,19$ & $-0,17$ & 0,53 & $-0,03$ & 0,09 & $-0,12$ & $-0,22$ & 0,03 & 0,64 & 0,03 \\
\hline Do you have enough variety in your work? & 0,51 & 0,05 & 0,21 & 0,30 & $-0,03$ & 0,43 & 0,18 & 0,32 & 0,25 & $-0,14$ & 0,21 & 0,46 & 0,23 & 0,22 & 0,11 \\
\hline $\begin{array}{l}\text { Does your job offer you opportunities for } \\
\text { personal growth and development? }\end{array}$ & 0,57 & 0,11 & 0,45 & 0,08 & 0,01 & 0,51 & 0,19 & 0,37 & 0,36 & $-0,10$ & 0,19 & 0,59 & 0,35 & 0,01 & 0,03 \\
\hline $\begin{array}{l}\text { Does your work give you the feeling that you can } \\
\text { achieve something? }\end{array}$ & 0,56 & 0,15 & 0,48 & 0,10 & $-0,03$ & 0,55 & 0,12 & 0,31 & 0,33 & $-0,11$ & 0,18 & 0,68 & 0,34 & $-0,08$ & 0,06 \\
\hline $\begin{array}{l}\text { Does your job offer you the possibility of } \\
\text { independent thought and action? }\end{array}$ & 0,55 & 0,18 & 0,39 & 0,13 & $-0,02$ & 0,70 & 0,02 & 0,23 & 0,17 & $-0,10$ & 0,24 & 0,71 & 0,21 & 0,07 & $-0,05$ \\
\hline $\begin{array}{l}\text { Do you have freedom in carrying out your } \\
\text { work activities? }\end{array}$ & 0,59 & 0,26 & 0,15 & $-0,03$ & $-0,05$ & 0,68 & 0,12 & 0,05 & 0,17 & $-0,12$ & 0,34 & 0,61 & 0,10 & $-0,02$ & $-0,05$ \\
\hline $\begin{array}{l}\text { Do you have influence in the planning of } \\
\text { your work activities? }\end{array}$ & 0,69 & 0,11 & 0,08 & 0,09 & $-0,07$ & 0,73 & 0,08 & 0,02 & 0,06 & $-0,04$ & 0,18 & 0,62 & 0,08 & 0,12 & $-0,02$ \\
\hline $\begin{array}{l}\text { Can you participate in the decision about when } \\
\text { a piece of work must be completed? }\end{array}$ & 0,61 & 0,16 & 0,06 & $-0,02$ & 0,02 & 0,60 & 0,10 & 0,08 & 0,05 & $-0,05$ & 0,30 & 0,61 & 0,12 & 0,06 & 0,04 \\
\hline $\begin{array}{l}\text { Can you count on your colleagues when you come } \\
\text { across difficulties in your work? }\end{array}$ & 0,07 & 0,62 & 0,02 & $-0,04$ & $-0,02$ & 0,13 & 0,66 & 0,10 & 0,11 & 0,03 & 0,33 & 0,56 & 0,03 & 0,02 & 0,16 \\
\hline If necessary, can you ask your colleagues for help? & $-0,04$ & 0,63 & 0,01 & $-0,06$ & $-0,07$ & 0,12 & 0,65 & 0,01 & 0,09 & 0,02 & 0,34 & 0,54 & $-0,03$ & $-0,04$ & 0,17 \\
\hline Do you get on well with your colleagues? & 0,03 & 0,53 & $-0,04$ & $-0,00$ & 0,01 & 0,02 & 0,58 & 0,11 & 0,09 & 0,01 & 0,34 & 0,45 & $-0,05$ & $-0,07$ & 0,18 \\
\hline $\begin{array}{l}\text { Can you count on your supervisor when you come } \\
\text { across difficulties in your work? }\end{array}$ & 0,29 & 0,58 & 0,30 & $-0,18$ & $-0,07$ & 0,07 & 0,81 & 0,05 & 0,14 & $-0,06$ & 0,64 & 0,38 & $-0,01$ & $-0,05$ & 0,03 \\
\hline Do you get on well with your supervisor? & 0,27 & 0,58 & 0,22 & $-0,18$ & 0,03 & 0,22 & 0,77 & $-0,05$ & 0,02 & $-0,10$ & 0,66 & 0,31 & $-0,03$ & $-0,03$ & 0,03 \\
\hline $\begin{array}{l}\text { In your work, do you feel appreciated by } \\
\text { your supervisor? }\end{array}$ & 0,34 & 0,60 & 0,36 & $-0,13$ & $-0,05$ & 0,38 & 0,66 & $-0,02$ & 0,10 & $-0,10$ & 0,72 & 0,27 & 0,06 & $-0,02$ & 0,03 \\
\hline $\begin{array}{l}\text { Do you know exactly what other people expect of } \\
\text { you in your work? }\end{array}$ & 0,24 & 0,64 & $-0,07$ & 0,08 & 0,01 & 0,59 & 0,08 & $-0,02$ & $-0,07$ & $-0,03$ & 0,45 & 0,37 & 0,06 & $-0,01$ & 0,10 \\
\hline Do you know exactly for what you are responsible? & 0,38 & 0,48 & $-0,18$ & 0,01 & 0,06 & 0,66 & 0,21 & 0,00 & $-0,03$ & $-0,08$ & 0,40 & 0,40 & $-0,01$ & 0,02 & 0,15 \\
\hline $\begin{array}{l}\text { Do you know exactly what your direct supervisor } \\
\text { thinks of your performance? }\end{array}$ & 0,30 & 0,62 & 0,24 & 0,03 & $-0,08$ & 0,45 & 0,38 & $-0,04$ & 0,09 & $-0,10$ & 0,74 & 0,09 & 0,12 & 0,03 & 0,03 \\
\hline $\begin{array}{l}\text { Do you receive sufficient information on the } \\
\text { purpose of your work? }\end{array}$ & 0,40 & 0,58 & 0,22 & 0,05 & $-0,09$ & 0,55 & 0,44 & $-0,05$ & 0,01 & $-0,13$ & 0,71 & 0,19 & 0,20 & $-0,00$ & $-0,00$ \\
\hline $\begin{array}{l}\text { Do you receive sufficient information on the results } \\
\text { of your work? }\end{array}$ & 0,34 & 0,61 & 0,17 & 0,02 & $-0,07$ & 0,58 & 0,34 & $-0,01$ & 0,10 & $-0,12$ & 0,75 & 0,16 & 0,26 & 0,02 & 0,02 \\
\hline $\begin{array}{l}\text { Does your direct supervisor inform you about } \\
\text { important issues within your department/organisation? }\end{array}$ & 0,29 & 0,64 & 0,31 & $-0,04$ & $-0,04$ & 0,44 & 0,49 & $-0,03$ & 0,16 & $-0,04$ & 0,76 & 0,08 & 0,23 & 0,03 & $-0,02$ \\
\hline $\begin{array}{l}\text { Are you kept adequately up-to-date about important } \\
\text { issues within your organisation? }\end{array}$ & 0,51 & 0,42 & 0,16 & $-0,05$ & $-0,10$ & 0,55 & 0,25 & 0,12 & 0,26 & $-0,00$ & 0,58 & 0,26 & 0,25 & $-0,06$ & 0,08 \\
\hline $\begin{array}{l}\text { Is the decision-making process of your organisation } \\
\text { clear to you? }\end{array}$ & 0,59 & 0,34 & 0,07 & $-0,06$ & $-0,02$ & 0,67 & 0,12 & 0,09 & 0,27 & $-0,03$ & 0,42 & 0,24 & 0,44 & $-0,07$ & 0,12 \\
\hline $\begin{array}{l}\text { Is it clear to you whom you should address within } \\
\text { the organisation for specific problems? }\end{array}$ & 0,54 & 0,41 & $-0,06$ & $-0,08$ & 0,00 & 0,54 & 0,35 & $-0,02$ & 0,15 & 0,04 & 0,44 & 0,29 & 0,24 & $-0,13$ & 0,11 \\
\hline $\begin{array}{l}\text { Can you discuss work problems with your } \\
\text { direct supervisor? }\end{array}$ & 0,42 & 0,55 & 0,17 & $-0,12$ & $-0,06$ & 0,34 & 0,72 & $-0,04$ & 0,08 & $-0,06$ & 0,72 & 0,29 & 0,04 & $-0,06$ & 0,03 \\
\hline $\begin{array}{l}\text { Can you participate in decisions about the } \\
\text { nature of your work? }\end{array}$ & 0,69 & 0,31 & 0,10 & $-0,08$ & $-0,04$ & 0,66 & 0,29 & 0,09 & 0,12 & $-0,09$ & 0,53 & 0,41 & 0,20 & 0,01 & 0,05 \\
\hline $\begin{array}{l}\text { Do you have a direct influence on your } \\
\text { organisation's decisions? }\end{array}$ & 0,68 & 0,06 & 0,08 & $-0,01$ & $-0,06$ & 0,68 & 0,01 & 0,16 & 0,21 & 0,01 & 0,27 & 0,26 & 0,42 & 0,07 & 0,06 \\
\hline $\begin{array}{l}\text { Do you need to be more secure that you will } \\
\text { still be working in one year's time? }\end{array}$ & $-0,08$ & $-0,11$ & $-0,09$ & 0,04 & 0,90 & $-0,11$ & $-0,04$ & 0,02 & $-0,06$ & 0,90 & 0,05 & 0,12 & 0,04 & 0,03 & 0,83 \\
\hline $\begin{array}{l}\text { Do you need to be more secure that you will } \\
\text { keep your current job in the next year? }\end{array}$ & $-0,08$ & $-0,06$ & $-0,10$ & 0,01 & 0,93 & $-0,18$ & $-0,05$ & $-0,02$ & $-0,05$ & 0,93 & 0,09 & 0,08 & 0,01 & 0,06 & 0,85 \\
\hline $\begin{array}{l}\text { Do you need to be more secure that next } \\
\text { year you will keep the same function } \\
\text { level as currently? }\end{array}$ & $-0,04$ & $-0,02$ & $-0,12$ & 0,05 & 0,85 & $-0,14$ & $-0,08$ & 0,03 & $-0,04$ & 0,88 & 0,06 & 0,07 & 0,06 & 0,03 & 0,73 \\
\hline Do you think that organisation pays good salaries? & 0,19 & 0,15 & 0,82 & $-1,01$ & $-0,12$ & 0,22 & 0,11 & 0,02 & 0,74 & 0,02 & 0,07 & 0,05 & 0,78 & 0,01 & 0,05 \\
\hline Can you live comfortably on your pay? & 0,13 & 0,12 & 0,79 & $-1,04$ & $-0,05$ & 0,16 & 0,04 & 0,01 & 0,75 & $-0,16$ & 0,11 & 0,04 & 0,80 & 0,03 & $-0,02$ \\
\hline $\begin{array}{l}\text { Do you think you are paid enough for the work } \\
\text { that you do? }\end{array}$ & 0,09 & 0,12 & 0,82 & $-0,08$ & $-0,06$ & 0,02 & 0,15 & $-0,10$ & 0,76 & 0,07 & 0,03 & $-0,02$ & 0,80 & $-0,07$ & 0,00 \\
\hline $\begin{array}{l}\text { Does your job offer you the possibility to } \\
\text { progress financially? }\end{array}$ & 0,24 & 0,14 & 0,73 & $-0,03$ & $-0,07$ & 0,38 & 0,18 & 0,06 & 0,69 & $-0,11$ & 0,12 & 0,10 & 0,81 & $-0,03$ & 0,02 \\
\hline $\begin{array}{l}\text { Does your organisation give you opportunities to } \\
\text { follow training courses? }\end{array}$ & 0,59 & 0,08 & 0,22 & $-0,10$ & $-0,01$ & 0,29 & 0,30 & 0,07 & 0,26 & 0,03 & 0,19 & 0,21 & 0,57 & $-0,05$ & $-0,01$ \\
\hline $\begin{array}{l}\text { Does your job give you the opportunity to } \\
\text { be promoted? }\end{array}$ & 0,36 & 0,12 & 0,47 & $-0,06$ & $-0,18$ & 0,21 & 0,34 & 0,13 & 0,43 & $-0,03$ & 0,13 & 0,16 & 0,65 & $-0,02$ & $-0,00$ \\
\hline
\end{tabular}


Do you have too much work to do?

Do you work under time pressure?

Do you have to be attentive to many things at the same time?

Do you have to give continuous attention to your work?

Do you have to remember many things in your work?

Are you confronted in your work with things that affect you personally?

Do you have contact with difficult people in your work?

Does your work put you in emotionally upsetting situations?

Do you have enough variety in your work? Does your job offer you opportunities for personal growth and development?

Does your work give you the feeling that you can achieve something?

Does your job offer you the possibility of independent thought and action?

Do you have freedom in carrying out your work activities?

Do you have influence in the planning of your work activities?

Can you participate in the decision about when a piece of work must be completed?

Can you count on your colleagues when you come across difficulties in your work?

If necessary, can you ask your colleagues for help?

Do you get on well with your colleagues?

Can you count on your supervisor when you come across difficulties in your work?

Do you get on well with your supervisor?

In your work, do you feel appreciated by your supervisor?

Do you know exactly what other people expect

of you in your work?

Do you know exactly for what you

are responsible?

Do you know exactly what your direct supervisor

thinks of your performance?

Do you receive sufficient information on the purpose of your work?

Do you receive sufficient information on the results of your work?

Does your direct supervisor inform you about important issues within your department/ organisation?

Are you kept adequately up-to-date about important issues within your organisation?

Is the decision-making process of your organisation clear to you?

Is it clear to you whom you should address within the organisation for specific problems?

Can you discuss work problems with your direct supervisor?

Can you participate in decisions about the nature of your work?

Do you have a direct influence on your organisation's decisions?

Do you need to be more secure that you will still be working in one year's time?

Do you need to be more secure that you will keep your current job in the next year? Do you need to be more secure that next year you will keep the same function level as currently?

Do you think that your organisation pays good salaries?

Can you live comfortably on your pay?

Do you think you are paid enough for the work that you do?

Does your job offer you the possibility to progress financially?

Does your organisation give you opportunities to follow training courses?

Does your job give you the opportunity to be promoted?
Group 4: University of Technology Group 5: Educators (Universities)

$\begin{array}{llllllllll}-0,16 & 0,04 & 0,71 & -0,12 & -0,02 & -0,10 & 0,07 & 0,69 & -0,03 & -0,00\end{array}$

$\begin{array}{lllllllllll}-0,13 & 0,04 & \mathbf{0 , 7 6} & -0,05 & -0,09 & -0,01 & -0,00 & \mathbf{0 , 7 3} & -0,06 & -0,01\end{array}$

$\begin{array}{llllllllll}-0,02 & 0,10 & 0,62 & -0,22 & 0,06 & 0,00 & 0,05 & \mathbf{0 , 6 9} & -0,06 & -0,07\end{array}$

$\begin{array}{llllllllll}0,03 & 0,34 & \mathbf{0 , 5 4} & -0,20 & 0,08 & 0,11 & 0,06 & \mathbf{0 , 6 0} & -0,07 & 0,04\end{array}$

$\begin{array}{llllllllll}0,06 & 0,43 & \mathbf{0 , 4 2} & -0,31 & 0,04 & 0,16 & 0,09 & \mathbf{0 , 6 5} & -0,11 & 0,05\end{array}$

$\begin{array}{llllllllll}-0,16 & -0,12 & \mathbf{0 , 5 2} & 0,04 & 0,09 & -0,22 & -0,10 & \mathbf{0 , 6 1} & 0,12 & 0,10\end{array}$

$\begin{array}{llllllllll}0,10 & -0,12 & \mathbf{0 , 5 5} & -0,05 & 0,07 & -0,15 & 0,08 & \mathbf{0 , 3 5} & 0,02 & 0,04\end{array}$

$\begin{array}{llllllllll}-0,16 & -0,24 & \mathbf{0 , 6 1} & 0,14 & 0,15 & -0,25 & -0,07 & \mathbf{0 , 5 1} & -0,05 & -0,06\end{array}$

$\begin{array}{llllllllll}0,19 & \mathbf{0 , 5 0} & 0,28 & 0,26 & -0,06 & 0,18 & \mathbf{0 , 6 3} & 0,21 & 0,14 & -0,00\end{array}$

$\begin{array}{llllllllll}0,31 & \mathbf{0 , 5 0} & 0,17 & 0,40 & -0,01 & 0,14 & \mathbf{0 , 7 7} & 0,06 & 0,17 & -0,06\end{array}$

$\begin{array}{llllllllll}0,46 & \mathbf{0 , 5 1} & 0,16 & 0,23 & -0,10 & 0,12 & \mathbf{0 , 8 1} & 0,09 & 0,13 & -0,09\end{array}$

$\begin{array}{llllllllll}0,27 & \mathbf{0 , 6 8} & 0,23 & 0,27 & -0,05 & 0,15 & \mathbf{0 , 8 0} & 0,06 & -0,03 & -0,10\end{array}$

$\begin{array}{llllllllll}0,41 & \mathbf{0 , 5 4} & -0,04 & 0,08 & -0,13 & 0,26 & \mathbf{0 , 6 4} & -0,10 & -0,01 & -0,05\end{array}$

$\begin{array}{llllllllll}0,37 & \mathbf{0 , 5 7} & 0,07 & 0,14 & -0,16 & 0,26 & \mathbf{0 , 5 5} & 0,02 & -0,02 & -0,02\end{array}$

$\begin{array}{llllllllll}0,32 & \mathbf{0 , 5 4} & 0,01 & 0,15 & -0,06 & 0,20 & \mathbf{0 , 5 2} & -0,01 & 0,16 & 0,02\end{array}$

$\begin{array}{llllllllll}0,23 & 0,52 & -0,31 & -0,03 & 0,14 & 0,46 & 0,25 & -0,18 & -0,11 & 0,14\end{array}$

$\begin{array}{llllllllll}\mathbf{0 , 1 7} & 0,54 & -0,28 & -0,01 & 0,14 & \mathbf{0 , 4 4} & 0,19 & -0,26 & -0,05 & 0,13\end{array}$

$\begin{array}{llllllllll}\mathbf{0 , 1 6} & 0,52 & -0,28 & -0,10 & 0,15 & \mathbf{0 , 4 8} & 0,11 & -0,18 & -0,14 & 0,15\end{array}$

$\begin{array}{llllllllll}0,72 & 0,26 & -0,12 & -0,14 & -0,04 & \mathbf{0 , 6 7} & 0,14 & -0,10 & -0,00 & 0,11\end{array}$

$\begin{array}{llllllllll}\mathbf{0 , 6 6} & 0,24 & -0,20 & -0,15 & 0,00 & \mathbf{0 , 7 3} & 0,13 & -0,10 & 0,02 & 0,04\end{array}$

$\begin{array}{llllllllll}\mathbf{0 , 7 9} & 0,13 & -0,06 & 0,11 & -0,01 & \mathbf{0 , 7 6} & 0,10 & -0,03 & 0,17 & -0,03\end{array}$

$\begin{array}{llllllllll}0,58 & 0,29 & -0,17 & 0,07 & -0,12 & \mathbf{0 , 6 4} & 0,01 & -0,04 & 0,01 & -0,12\end{array}$

$\begin{array}{llllllllll}\mathbf{0 , 5 1} & 0,34 & -0,19 & -0,06 & -0,09 & \mathbf{0 , 5 0} & 0,17 & -0,13 & 0,01 & -0,02\end{array}$

$\begin{array}{llllllllll}\mathbf{0}, 84 & 0,00 & -0,03 & 0,15 & -0,03 & \mathbf{0 , 7 6} & 0,07 & 0,03 & 0,19 & -0,12\end{array}$

$\begin{array}{llllllllll}\mathbf{0 , 7 2} & 0,21 & -0,12 & 0,17 & -0,01 & \mathbf{0 , 7 2} & 0,19 & 0,01 & 0,10 & -0,14\end{array}$

$\begin{array}{llllllllll}\mathbf{0 , 7 3} & 0,14 & -0,04 & 0,17 & -0,01 & \mathbf{0 , 7 0} & 0,12 & 0,04 & 0,20 & -0,07\end{array}$

$\begin{array}{llllllllll}\mathbf{0}, 82 & 0,08 & -0,02 & 0,14 & 0,02 & \mathbf{0 , 7 3} & -0,01 & 0,04 & 0,22 & -0,07\end{array}$

$\begin{array}{llllllllll}\mathbf{0 , 6 8} & 0,21 & -0,04 & 0,12 & -0,12 & \mathbf{0 , 5 7} & 0,18 & 0,01 & 0,21 & -0,07\end{array}$

$\begin{array}{llllllllll}\mathbf{0 , 6 5} & 0,16 & -0,04 & 0,11 & -0,11 & \mathbf{0 , 5 6} & 0,15 & 0,03 & 0,24 & -0,16\end{array}$

$\begin{array}{llllllllll}\mathbf{0 , 5 2} & 0,41 & -0,05 & -0,11 & 0,03 & \mathbf{0 , 6 3} & 0,15 & -0,03 & 0,00 & -0,02\end{array}$

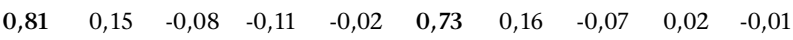

$\begin{array}{llllllllll}\mathbf{0 , 7 1} & 0,39 & -0,01 & 0,10 & 0,06 & \mathbf{0 , 6 5} & 0,35 & -0,01 & 0,05 & -0,13\end{array}$

$\begin{array}{llllllllll}\mathbf{0}, 59 & 0,20 & 0,18 & 0,28 & 0,00 & 0,40 & 0,37 & 0,17 & 0,12 & -0,15\end{array}$

$\begin{array}{llllllllll}-0,10 & 0,03 & 0,03 & -0,11 & 0,89 & -0,07 & -0,08 & 0,05 & 0,03 & 0,88\end{array}$

$\begin{array}{llllllllll}-0,09 & -0,04 & 0,10 & -0,08 & \mathbf{0 , 9 2} & -0,08 & -0,11 & 0,03 & 0,04 & 0,92\end{array}$

$\begin{array}{llllllllll}-0,06 & 0,02 & 0,11 & -0,02 & 0,87 & -0,09 & -0,12 & 0,02 & -0,01 & 0,86\end{array}$

$\begin{array}{llllllllll}-0,01 & 0,22 & -0,14 & 0,73 & -0,02 & 0,21 & 0,03 & -0,05 & 0,76 & 0,10\end{array}$

$\begin{array}{llllllllll}-0,01 & 0,04 & -0,11 & \mathbf{0 , 7 7} & -0,16 & 0,06 & 0,11 & -0,02 & 0,78 & 0,05\end{array}$

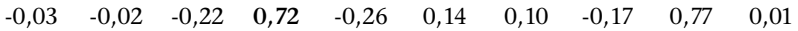

$\begin{array}{llllllllll}0,18 & 0,04 & -0,04 & 0,73 & 0,02 & 0,12 & 0,25 & 0,01 & 0,71 & -0,05\end{array}$

$\begin{array}{llllllllll}0,32 & 0,28 & -0,04 & 0,34 & 0,05 & 0,26 & 0,25 & -0,18 & 0,25 & -0,14\end{array}$

$\begin{array}{llllllllll}0,27 & 0,03 & 0,02 & \mathbf{0 , 4 6} & 0,09 & 0,04 & 0,48 & -0,05 & 0,37 & -0,08\end{array}$ 
TABLE 4

TUCKER'S PHI COEFFCIENTS OF THE FACTORS OF THE JDRS

\begin{tabular}{|c|c|c|c|c|c|}
\hline & 1 & 2 & 3 & 4 & 5 \\
\hline Insurance Industry & 0,94 & 0,96 & 0,94 & 0,97 & 0,97 \\
\hline Engineering Industry & 0,94 & 0,89 & 0,97 & 0,95 & 0,97 \\
\hline Correctional Officers & 0,99 & 0,97 & 0,98 & 0,99 & 0,98 \\
\hline University of Technology & 0,96 & 0,94 & 0,96 & 0,97 & 0,96 \\
\hline $\begin{array}{l}\text { Academics (Higher Education } \\
\text { Institutions) }\end{array}$ & 0,99 & 0,96 & 0,98 & 0,98 & 0,98 \\
\hline
\end{tabular}

TABLE 5

DESCRIPTIVE STATISTICS, ALPHA COEFFICIENTS AND PEARSON CORRELATIONS OF THE JDRS

\begin{tabular}{lccccccc}
\hline & Mean & SD & $\alpha$ & 1 & 2 & 3 & 4 \\
\hline 1. Growth Opportunities & 19,50 & 4,75 & 0,86 & - & - & - & - \\
2. Organisational Support & 51,85 & 10,71 & 0,92 & $0,65^{*++}$ & - & - & - \\
3. Advancement & 12,66 & 4,26 & 0,83 & $0,46^{*}+0,42^{*+}$ & - & - \\
4. Overload & 22,18 & 4,18 & 0,76 & $0,16^{*}$ & $-0,04$ & $-0,01$ & - \\
5. Job Insecurity & 7,63 & 3,02 & 0,89 & $-0,14^{*}$ & $-0,11^{*}$ & $-0,16^{*}$ & $-0,01$ \\
\hline
\end{tabular}

* Statistically significant: $\mathrm{p}<0,01$

+ Practically significant (medium effect): $r>0,30$

++ Practically significant (large effect): $r>0,50$

TABLE 6

MANOVA WITH ORgANISATION AS INDEPENDENT VARIABLE AND JOB DEMANDS AND RESOURCES AS DEPENDENT VARIABLES

\begin{tabular}{lcccccc}
\hline Variable & Value & $\mathbf{F}$ & $\mathbf{d f}$ & Error df & $\mathbf{p}$ & $\mathbf{h}^{2}$ \\
\hline Organisation & 0,70 & 52,01 & 4 & 8982,37 & $0,00 *$ & 0,09 \\
\hline
\end{tabular}

* Statistically significantly: $p<0,01$

TABLE 7

MEANS AND STANDARD DEVIATIONS OF JOB DEMANDS AND RESOURCES

\begin{tabular}{llccc}
\hline Type & Group & Mean & SD & n \\
\hline Growth opportunities & Insurance Industry & 18,66 & 4,17 & 613 \\
& Engineering Industry & 22,30 & 3,97 & 369 \\
& Correctional Services & 18,44 & 5,00 & 892 \\
& University of Technology & 19,21 & 4,81 & 372 \\
& Academics (Higher & 20,62 & 4,39 & 471 \\
& Education Institutions) & & & \\
Organisational support & Insurance Industry & 53,21 & 9,42 & 613 \\
& Engineering Industry & 55,80 & 9,08 & 369 \\
& Correctional Services & 49,23 & 11,32 & 892 \\
& University of Technology & 50,45 & 11,53 & 372 \\
& Academics (Higher & 53,03 & 10,18 & 471 \\
& Education Institutions) & & & \\
& Insurance Industry & 12,46 & 4,05 & 613 \\
& Engineering Industry & 15,68 & 3,86 & 369 \\
& Correctional Services & 12,12 & 4,67 & 892 \\
& University of Technology & 12,34 & 3,61 & 372 \\
& Academics (Higher & 11,82 & 3,45 & 471 \\
& Education Institutions) & & &
\end{tabular}

\begin{tabular}{lllll} 
Overload & Insurance Industry & 22,74 & 3,76 & 613 \\
& Engineering Industry & 23,78 & 3,53 & 369 \\
Correctional Services & 21,68 & 4,52 & 892 \\
& University of Technology & 22,69 & 3,83 & 372 \\
Academics (Higher & 23,32 & 4,18 & 471 \\
Education Institutions) & & & \\
Job insecurity & Insurance Industry & 7,50 & 2,82 & 613 \\
& Engineering Industry & 5,27 & 2,54 & 369 \\
Correctional Services & 8,85 & 2,60 & 892 \\
& University of Technology & 8,15 & 2,92 & 372 \\
& Academics (Higher & & & \\
Education Institutions) & 6,95 & 3,12 & 471 \\
\hline
\end{tabular}

\section{DISCUSSION}

The aims of this study were to investigate the construct validity, construct equivalence and reliability of a measuring instrument of job demands and resources and to assess the differences between the job demands and resources in different organisations in South Africa. The results showed that the JDRS is valid, reliable and equivalent for different organisations. Significant differences were found in terms of job demands and job resources in different organisations.

With regard to the construct (factorial) validity, evidence was found for five dimensions of job demands and resources, namely overload, job insecurity, growth opportunities, advancement and organisational support. Overload refers to the amount of work, mental load and emotional load. Job insecurity refers to feeling insecure in the current job and level with regard to the future thereof. Growth opportunities refer to having enough variety, opportunities to learn and independence in your work. Advancement means moving forward within your work and includes remuneration, training and career opportunities. Organisational support refers to relationships with your supervisor/manager, the availability of information, communication in the organisation, participation, social support by colleagues, and contact opportunities within the organisation (Jackson \& Rothmann, 2005).

A second-order factor analysis, which was conducted using the five observed factors, resulted in a two-factor structure. The first factor represented job demands (overload). The second factor represented job resources (i.e. growth opportunities, organisational support, advancement and job security). These factors correspond with the two factors found by Demerouti et al. (2001) and Schaufeli and Bakker (2004). Therefore, it seems that the factorial structure of job demands and job resources is valid. The results in this study are similar to those reported by Demerouti et al. (2001) who stated that different work characteristics can be grouped into the two categories of job demands and job resources.

Regarding the equivalence of the JDRS, the results showed acceptable Tucker's phi values for the five factors within the different organisations. Therefore, the general framework in the Job Demands-Resources model seems to be stable across the five different organisations (Demerouti et al., 2001). The only exception was on organisational support which showed a slightly lower than acceptable equivalence. It is not clear why items related to social support loaded on the factor which measured growth opportunities (i.e. intrinsic job characteristics) in these organisations. A possible explanation for this finding is that the structure of organisational support for correctional officers and staff members at a university of technology is somewhat 
different from other organisations as far as social support is concerned. In these two organisations social support is regarded as inherent in the job rather than just a form of support from the organisation. Probably social support is perceived as a very important part of the nature of the job. The strong loadings of social support items on growth opportunities in these two samples support this notion. An item related to having a direct influence on the organisation's decisions (which is supposed to be a form of organisational support), loaded on growth opportunities in the correctional officer sample as well as the sample of employees in the insurance industry.

Engineers showed statistically significantly higher scores on overload than employees in the insurance industry. Correctional officers experienced less job demands (overload) than the insurance staff as well as the university of technology and academics in higher education institutions. Engineers and academics in higher education institutions experienced the highest overload. Engineers experienced the highest growth opportunities of all the organisations. The combination of high overload and high growth opportunities probably makes the engineering profession a challenging (rather than just a stressful) one (Jackson \& Rothmann, 2005). Academics in higher education institutions also experienced higher growth opportunities than the other groups, while correctional officers experienced the least growth opportunities. The finding that academics in higher education institutions experience overload is in line with the findings of Koorts (2000), Nixon et al. (2001), and Fisher (1994). However, the growth opportunities (e.g. variety, learning opportunities and autonomy) inherent in job in academia, might contribute to perceptions that the job is challenging.

Engineers, academics in higher education institutions and employees in the insurance industry reported higher levels of organisational support than correctional officers and employees of a university of technology. The lack of organisational support for correctional officers has also been pointed out by Maghan and McLeish-Blackwell (1991) and Rothmann (2005). Engineers obtained higher scores on advancement than the other groups. However, academics in higher education institutions reported the least advancement opportunities.

Job insecurity was the highest for correctional officers and employees at a university of technology, and the lowest for engineers. The high levels of job insecurity of correctional officers and employees at a university of technology might be related to the transformation that is taking place in these organisations. Correctional services and the university of technology in South Africa experienced major changes in their organisational strategies and cultures since 1994. Correctional services accepted a new focus because of a new culture of human rights in South Africa. At the same time they have to deal with problems, such as overcrowded prisons and dangerous criminals. The university of technology changed from a technikon to a university (resulting in new strategies and ways of doing business). Compared to the other organisations that were studied, these two organisations also experienced the most changes in their staff components (because of the implementation of employment equity). Therefore, employees were not only more insecure about their jobs within the next year, but also in terms of the job levels that they would find themselves.

This study had various limitations. Firstly, the sample sizes of all the organisations were not equal, which could have influenced the results of the factor analyses. Secondly, only five organisations were included in this study. It is necessary to include more occupations and organisations in future studies with the JDRS. Thirdly, in this study participants were classified according to organisation. For instance, although academics in higher education institutions were regarded as an organisation, the participants represented academics at various job levels and higher education institutions in South Africa. In future studies it might be useful to analyse the data of all organisations and all occupations separately.

\section{Recommendations}

Various application-oriented suggestions were generated by this study. First, the results supported the construct validity and structural invariance of the JDRS for different organisations. Therefore, the JDRS could be utilised to measure and compare job demands and job resources in different organisations. Second, this study showed that job demands and job resources in different organisations were different. Knowledge of these differences could be used to plan interventions to promote the work-related well-being of employees. However, before interventions are implemented, more research is needed regarding the effects of job demands and resources on employees' energy and identification with their work.

Studies are needed regarding the construct validity and construct equivalence of the JDRS in other organisations and occupations. More research is needed regarding job demands and resources in different occupations and organisations in South Africa, to develop a measure which could be used in a wide variety of contexts. This information can be used not only to plan and structure interventions, but also to inform human resource policies in organisations.

Future studies should also investigate the immediate and longterm effects of specific job demands and resources in each occupation or organisation on employee health and wellness, as well as the outcomes thereof. Ecological Momentary Assessment (EMA) could be used to assess how employees experience job demands and job resources on a momentary basis in the natural environment (Stone \& Shiffman, 1994). EMA permits the examination of events in their natural, spontaneous context that provides information that is complimentary to that obtainable from the cross-sectional type of design that was used in this study.

\section{Author's Note}

This material is based upon work supported by the National Research Foundation under Grant number 2053344.

\section{REFERENCES}

Anson, R.H. \& Bloom, M.E. (1988). Police stress in an occupational context. Journal of Police and Administration, 16, 229-235.

Anson, R.H., Johnson, B. \& Anson, N.W. (1997). Magnitude and sources of general and occupation specific stress among police and correctional officers. Journal of Offender Rehabilitation, 25, 103-113.

Bakker, A.B., Demerouti, E. \& Schaufeli, W.B. Dual processes at work in a call centre: An application of the job demandsresources model. European Journal of Work and Organizational Psychology, 12, 393-417.

Bakker, A.B., Demerouti, E. \& Schaufeli, W.B. (2003). Dual processes at work in a call centre: An application of the job demands-resources model. European Journal of Work and Organizational Psychology, 12, 393-417.

Bakker, A.B., Demerouti, E., Taris, T.W., Schaufeli, W.B. \& Schreurs, P.J.G. (2003). A multigroup analysis of the Job Demands-Resources Model in four home care organizations. International Journal of Stress Management, 10 (1), 16-38.

Bakker A.B., Schaufeli, W.B., Sixma, H.J. \& Bosveld, W. (2001). Burnout contagion among general practitioners. Journal of Social and Clinical Psychology, 20, 82-98. 
Barkhuizen, N. \& Rothmann, S. (in press). Work wellness of academic staff in South African higher education institutions. Manuscript submitted for publication.

Barling, J. (1999). Changing employment relations: Empirical data, social perspectives and policy options. In D.B. Knight \& A. Joseph (Eds.). Restructuring societies: Insights from the social sciences (pp. 59-82). Ottawa: Carlton University Press.

Chan, K.B. (2002). Coping with work stress, work satisfaction and social support: An interpretive study of life insurance agents. Journal of Social Sciences, 30, 657-685.

Coetzer, W.J. (2004). Burnout and work engagement of employees in as insurance company. Unpublished doctoral thesis, NorthWest University, Potchefstroom.

Cohen, J. (1988). Statistical power analysis for the behavioural science (2nd ed.). Hillside, NJ: Erlbaum.

De Jonge, J. \& Kompier, M.A.J. (1997). A critical examination of the Demand-Control-Support model from a work psychological perspective. International Journal of Stress Management, 4, 235-258.

Demerouti, E., Bakker, A.B., Nachreiner, F. \& Schaufeli, W.B. (2001). The job demands-resources model of burnout. Journal of Applied Psychology, 86, 499-512.

Doyle, C. \& Hind, P. (1998). Occupational stress, burnout and job status in female academics. Gender, Work and Organisations, 5, 67-82.

Elsass, P.M. \& Veiga, J.F. (1997). Job control and job strain: A test of three models. Journal of Occupational Health Psychology, 2, 195-211.

Finn, P. (1998). Correctional officer stress: A cause for concern and additional help. Federal Probation, 62, 65-74.

Fisher, S. (1994). Stress in academic life: The mental assembly line. Buckingham, UK: Open University Press.

Flanagan, T.J., Johnson, W. \& Wesley, E. (1996). Job satisfaction among correctional executives: A contemporary portrait of wardens of state prisons for adults. Prison Journal, 76 (4), 13-15.

Ganster, D.C. \& Fusilier, M.R. (1989). Control in the workplace. In C. L. Cooper \& I. T. Robertson (Eds.). International review of industrial and organisational psychology (pp. 235-280). Chichester, UK: Wiley.

Hackman, J.R. \& Oldham, G.R. (1980). Work redesign. Reading, MA: Addison-Wesley.

Hassine, V. (1996). Life without parole. Los Angeles: Roxbury.

Hobfoll, S.E. (1989). Conservation of resources: A new attempt at conceptualizing stress. American Psychologist, 44, 513-524.

Hobfoll, S.E. (1998). Stress, culture and community: The psychology and philosophy of stress. New York: Plenum.

Hobfoll, S.E. (2001). The influence of culture, community, and the nested-self in the stress process: Advancing conservation of resources theory. Applied Psychology: An International Review, 50, 337-370.

Hobfoll, S.E. \& Freedy, J. (1993). Conservation of resources: A general stress theory applied to burnout. In W.B. Schaufeli, C. Maslach \& T. Marek. (Eds.), Professional burnout: Recent developments in theory and practice (pp. 115-129). Washington, DC: Taylor \& Francis.

Jackson, L.T.B. \& Rothmann, S. (2005). Work-related well-being of educators in a district of the North West Province. Perspectives in Education, 23, 107-122.

Karasek, R.A. (1979). Job demands, job decision latitude, and mental strain: Implications for job design. Administrative Science Quarterly, 24, 285-308.

Karasek, R.A. \& Theorell, T. (1990). Healthy work: Stress, productivity, and the recognition of working life. New York: Basic Books.

Kerlinger, F.N. \& Lee, H.B. (2000). Foundations of behavioral research (4th ed.). Orlando, FL: Harcourt College Publishers.

Koorts, A.S. (2000). Global, social and economic influences on the access policies of South African Higher Education. Higher Education in Europe, 25, 381-387.
Lai, G., Chan, K.B, Ko, Y.C. \& Boey, K.W. (2000). Institutional context and stress appraisal: The experience of life insurance agents in Singapore. Journal of Asian \& African Studies, 35, 209-228.

Lee, R.T. \& Ashforth, B.E. (1996). A meta-analytic examination of the correlates of the three dimensions of job burnout. Journal of Applied Psychology, 81, 123-133.

Lindstrom, K., Leino, T., Seitsamo, T. \& Tordtila, L. (1997). A longitudinal study of work characteristics and health complaints among insurance employees in VTD work. International Journal of Human Computer Interaction, 9 , 343-368.

Maghan, J. \& McLeish-Blackwell, L. (1991). Black women in correctional employment. In J.B. Morton (Ed.), Change, challenges, and choices: Women's role in modern corrections (pp. 82-99). Laurel, Maryland: American Correctional Association.

Meijman, T.F. \& Mulder, G. (1998). Psychological aspects of workload. In P.J. Drenth, H. Thierry \& C.J. de Wolff (Eds.). Handbook of work and organisational psychology (2nd ed. pp. 533). Hove: Psychology Press.

Naidu, B. (2005, July 10). R6m to help teachers fight stress. Sunday Times.

Nelson, D.L. \& Simmons, B.L. (2003). Health psychology and stress: A more positive approach. In J.C. Quick \& L.E. Tetrick (Eds.), Handbook of occupational health and psychology (pp. 97-117). Washington, DC: American Psychological Association.

Nixon, J., Marks, A., Rowland, S. \& Walker, M. (2001). Towards a new academic professionalism: A manifesto of hope. British Journal of Sociology of Education, 22, 227-244.

Nunnally, J.C. \& Bernstein, I.H. (1994). Psychometric theory (3 ${ }^{\text {rd }}$ ed.). New York: McGraw-Hill.

Rothmann, S. (2003). Burnout and engagement: A South African perspective. South African Journal of Industrial Psychology, 29 (4), 16-25.

Rothmann, S. (2005, August). Occupational stress, organizational commitment and ill health in South African organizations. Paper presented at the $2^{\text {nd }}$ ICOH International Conference on Psychosocial Factors at Work, Okayama, Japan.

Rothmann, S. \& Cilliers, F.V.N. (2004, May 28). Shifting the boundaries of knowledge: The contribution of industrial psychology. Paper presented at the National Research Foundation Conference, Tshwane University of Technology, Pretoria.

Schaufeli, W.B. (2003). Past performance and future perspectives of burnout research. South African Journal of Industrial Psychology, 29 (4), 1-15.

Schaufeli, W.B. \& Bakker, A.B. (2004). Job demands, job resources, and their relationship with burnout and engagement: A multi-sample study. Journal of Organizational Behavior, 25, 1-23.

Schaufeli, W.B. \& Enzmann, D. (1998). The burnout companion to study and practice: A critical analysis. London: Taylor \& Francis.

Semmer, N., Zapf, D. \& Dunckel, H. (1995). Assessing stress at work: A framework and an instrument. In O. Svane \& C. Johansen (Eds.). Work and health - Scientific basis of progress in the working environment (pp. 105-113). Luxembourg: Office for Official Publications of the European Communities.

SPSS Inc. (2003). SPSS 12.0 for Windows. Chicago, IL: Author.

Steyn, H.S. (1999). Praktiese betekenisvolheid: Die gebruik van effekgroottes. Wetenskaplike bydrae - Reeks B: Natuurwetenskappe Nr 1170, Potchefstroom: PU vir CHO.

Stone, A.A. \& Shiffman, S. (1994). Ecological momentary assessment (EMA) in behavioral medicine. Annals of Behavioral Medicine, 16, 199-202.

Tabachnick B.G. \& Fidell, L.S. (2001). Using multivariate statistics ( $4^{\text {th }}$ ed.). Boston, MA: Allyn \& Bacon.

Terry, D.J. \& Jimmieson, N.L. (1999). Work control and employee well-being: A decade review. In C.L. Cooper \& I.T. Robertson 
(Eds.). International review of industrial and organisational psychology (pp. 95-148). Chichester: Wiley.

Toch, H. (1992). Mosaic of despair: Human breakdowns in prison (Revised ed.). Washington, DC: American Psychological Association.

Turner, N., Barling, J. \& Zacharatos, A. (2002). Positive psychology at work. In C.R. Snyder \& S.J. Lopez (Eds.). Handbook of positive psychology (pp. 715-728). Oxford, UK: Oxford University Press.

Van de Vijver, F. \& Leung, K. (1997). Methods and data analysis for cross-cultural research. Thousand Oaks, CA: Sage.
Van Horn, J.E., Schaufeli, W.B. \& Enzmann, E. (1999). Teacher burnout and lack of reciprocity. Journal of Applied Social Psychology, 29, 91-108.

Warr, P.B. (1987). Work, unemployment and mental health. Oxford, UK: Clarendon Press.

Zapf, D., Vogt, C., Seifert, C., Mertini, H. \& Isic, A. (1999). Emotion work as a source of stress: The concept and development of an instrument. European Journal of Work and Organizational Psychology, 8, 371-400. 